\title{
Motives, facilitators and constraints of environmental management in the Caribbean accommodations sector
}

\author{
Mechelle N. Best ${ }^{\mathrm{a}}$, Brijesh Thapa ${ }^{\mathrm{b}, \mathrm{c}, *}$ \\ ${ }^{a}$ Department of Recreation and Tourism Management, California State University - Northridge, Northridge, CA 91330, USA \\ ${ }^{\mathrm{b}}$ Eric Friedheim Tourism Institute, Department of Tourism, Recreation \& Sport Management, University of Florida, Gainesville, FL 32611, USA \\ ${ }^{\mathrm{c}}$ Department of Tourism Management, Tshwane University of Technology, Pretoria, South Africa
}

\section{A R T I C L E I N F O}

\section{Article history:}

Received 27 July 2012

Received in revised form

27 January 2013

Accepted 3 March 2013

Available online 13 March 2013

\section{Keywords:}

Motives

Constraints

Facilitators

Caribbean

Environmental management

Accommodations

\begin{abstract}
A B S T R A C T
The Caribbean accommodations sector has embarked on a course of 'greening' or instituting environmental management (EM). In order to further explore this EM movement, this study sought to examine motives, facilitators, and constraints to implementing EM based on diffusion of innovations theory. Data were collected through an online survey of 197 hotels in 19 countries. Two-thirds of the accommodations sector had implemented some level of EM from basic initiatives to certified environmental management systems. Descriptive and statistical analysis were employed to understand motives, facilitators, and constraints to implementing EM. Based on logistic analysis, a single motive item, internal green champion was significantly associated with level of environmental management implemented, while none of the facilitator items were statistically significant. However, several constraints such as lack of capital, potential benefits not apparent, no access to technology, lack of know-how, EM is not necessary and, lack of time were all predictors of EM. Based on the results, several recommendations were made to strengthen the greening efforts in the region.
\end{abstract}

(C) 2013 Elsevier Ltd. All rights reserved.

\section{Introduction}

Tourism development and the ongoing operation of enterprises have generally not occurred with significant regard for nature conservation and protection, especially in the Caribbean where tourism is extremely dependent on natural resources. For example, construction of hotels and other tourism facilities in some coastal areas in Barbados, St. Lucia and Jamaica have resulted in the destruction of mangrove forests and in-filling of hundreds of acres of wetlands, thereby reducing the ability of the ecosystem to perform services such as nutrient filtering, control of freshwater injection to the marine environment, and provision of food and habitat for local and migratory birds (Bacon, 1987; Burke, 2007; Carrier and Macleod, 2005). Other negative impacts that ensue from tourism development include beach erosion, deforestation, loss of vegetation, soil erosion, pollution of coastal waters, and coral reef loss (de Albuquerque and McElroy, 1995; Wilkinson, 1987). Although development impacts are often exacerbated by the post-

\footnotetext{
* Corresponding author. Eric Friedheim Tourism Institute, Department of Tourism, Recreation \& Sport Management, University of Florida, Gainesville, FL 32611, USA. Tel.: +1 352294 1656; fax: +1 3523927588 .
}

E-mail address: bthapa@hhp.ufl.edu (B. Thapa). construction operations of tourism enterprises, only limited measures to reduce such impacts have been legislated in Caribbean destinations (Mycoo, 2006).

In the Caribbean, the sustainable tourism discourse is ongoing with commitments by some governments which are only slowly evolving to advance the rhetoric to policy and/or practical application. Furthermore, it has been suggested that sustainable tourism in Caribbean destinations is not possible without legislative action to support verbal commitments (Sinclair and Jayawardena, 2003). The discourse on sustainable tourism has not been limited to the level of regional governments, but has perhaps to a greater extent been taken up by the private sector partners of the industry. The Caribbean tourism industry has been developing and implementing environmental programs which seek to improve their impact on the biophysical environment and host community. Since the mid 1990s, stakeholders of Caribbean tourism especially the accommodations sector have implemented various initiatives to improve their impact on the natural environment which fall under the broad umbrella of 'greening' or environmental management (EM). In the wider Caribbean, these efforts and systematic implementation of EM in the accommodations sector have been spearheaded by the Caribbean Alliance for Sustainable Tourism (CAST) which was created by the Caribbean Hotel Association (CHA) in 1997. 
In its early years, CAST was a leader in the region facilitating the emergence of different levels of $\mathrm{EM}^{1}$ in the accommodations sector which range from the implementation of a few basic initiatives such as the replacement of inefficient lighting in key areas, to a full scale benchmark and certified ${ }^{2}$ Environmental Management Systems (Blanchard and Lorde, 2004; Brown-Thompson and Cresser, 2004). The implementation of EM in the accommodations sector has largely been adopted due to the promotion of benefits advocated such as improved impacts on the natural environment, increased efficiencies, reduced operating costs, improved relationships with the wider community, and improved staff morale (Bohdanowicz, 2005; Goodman, 2000; Meade and Pringle, 2001; Vernon et al., 2003).

Despite the increased adoption of greening initiatives in the Caribbean, there is limited empirical research on EM in the hospitality and tourism industry, though some studies have been conducted in the region (Best, 2002, 2004; Kingsbury, 2006; Meade and del Monaco, 1999; Meade and Pringle, 2001; Mycoo, 2006; Poon, 1987). This study attempts to fill a gap in existing research in the Caribbean. Based on the diffusions of innovations conceptual framework (Rogers, 2003), this study sought to examine motives, facilitators, and constraints to implementing EM in the Caribbean accommodations sector. The following sections will provide a literature review with respect to the utility of diffusion of innovations theory in this research, and also motives, facilitators, and constraints that influence the implementation of EM in the accommodations industry. Following the review, the methods section will outline the data collection process, sample description, and the survey instrument used in this study. Subsequently, the results will report on the findings based on empirical analysis of the four research questions. Finally, the discussion section will interpret the findings, offer management and policy implications, and also note the limitations and recommendations for future research.

\section{Environmental management: literature review \& research questions}

\subsection{Diffusion of innovations}

An innovation can be any product, system, management style, service, idea, or a combination which is new and has potential applicability and benefits. Diffusion of innovation is the process by which the given innovation is adopted and spread within a social system over time (Bigoness and Perreault, 1981; Rogers, 2003; Strang and Soule, 1998). Diffusion of innovation studies came to the fore with the work of rural sociologists Ryan and Gross (1943) on the use of hybrid corn by farmers in Iowa (Rogers, 2003). The study was aimed at understanding why hybrid corn seed was not quickly adopted by most farmers, and examined rates of adoption and the differences between innovators and later adopters. Interviews were conducted with farmers who were asked to recall the time of adoption, sources of information on the innovation, and consequences of adopting the innovation (Rogers, 2003; Ryan and Gross, 1943). Following this study, these elements have been used in most diffusion research in a range of disciplines including public health, communication, anthropology, and education (Rogers, 2003).

\footnotetext{
1 In this study, environmental management is defined as management of the body of policies or actions which, impact the biophysical environment. It is also noteworthy that in some instances environmental management also, subsumes policies and actions within the broader socio-cultural context.

2 International standards such as Green Globe or the International Organization for Standardization.
}

In more recent decades, diffusion of innovations theory has also been used in the recreation and tourism discipline to understand the implications of information technology and other innovations in international tourism for the Caribbean tourism industry (Poon, 1987); transportation systems in U.S. National Parks (Dilworth, 2003); intention of the public to visit a new urban park in Ohio (Mowen and Confer, 2003); likelihood to adopt environmental management practices in hotels in Vietnam (Le et at., 2006); and the use of technologies such as, website development and email as a means for marketing and communications (Murphy et al., 2003; Sahadev and Islam, 2005; Smith, 2007).

In the context of the accommodations sector, there are several examples of adoption and non-adoption of innovation. Murphy et al. (2003) examined email technology as an innovation within a stratified sample of websites of 200 hotels from the Swiss Hotel Association. Results identified significant relationships between hotel characteristics (size, category, location, and linguistic region) and the adoption of email technology. Sahadev and Islam (2005) conducted research that pertained to factors that influence Thai hotels' propensity (relative time taken) to adopt information and communication technology. Seven factors were used as independent variables: hotel age, size, type, range of activities, proportion of visitors from the hotel's high-penetration countries, level of competition between local hotels, and market size. Hotel's age was the only factor found to significantly influence the propensity of Thai hotels to adopt information and communication technologies (Sahadev and Islam, 2005).

Le et al. (2006) utilized diffusion of innovations to investigate the factors that influence the likelihood of hotels to adopt environmental management practices in Vietnam (Le et al., 2006). The factors were segmented into three main categories: perceived innovation characteristics (complexity, observability, compatibility, relative advantage), environmental characteristics (competition, customer demand, government regulation), and organizational characteristics (size, location, level of risk-taking, and greenness level). Data were collected via a self-administered questionnaire completed by owners, managers, or other decision makers of hotels. Results noted that innovation characteristics, especially complexity and observability had the strongest influence on hotels' likelihood to adopt environmentally friendly practices. Other influential factors were relative advantage, size, location, level of risk-taking, and perceived competition (Le et al., 2006).

With respect to the Caribbean, Poon (1987) examined the influence of hotel structure, organization, ownership and management in adopting new technologies that would improve their competitiveness. It was found that hotels' innovativeness was most influenced by the caliber of managers and their willingness to embrace changes and innovations. Poon (1987) proposed a combination of progressive, intelligent, and customer-focused management, honed skills, and consistent innovation would be needed in Caribbean hotels.

Since the emergence of diffusion of innovations theory, it has been consistently applied to research in developing countries (Rogers, 2003). Additionally, the theory has been used to investigate innovations in the accommodations sector as well as the wider tourism industry in the Caribbean, and other destinations. Overall, environmental management is an innovation in the Caribbean accommodations sector; the use of diffusion of innovations theory to examine the adoption and impact of EM in the sector is applicable and explored in this study.

\subsection{Environmental management}

Environmental management encompasses measures taken to protect the environment from harmful anthropogenic impacts so as 
to sustain resources over time. Although legislations in many developed countries has mandated the implementation of some form of EM in the manufacturing industry (Meyer, 2000), the transition to the service sector has been much slower (Kassinis and Soteriou, 2003). Yet, the service industry has been noted to create various negative impacts to the natural environment, whether through its consumption of manufactured products or through facility construction and operational activities (Burke and Maidens, 2004). Indeed, the accommodations sector may consume significantly more resources and generate double or triple the amount of waste in comparison to residents (Burke, 2007; Gossling, 2002).

The establishment of the International Hotels Environment Initiative - now the International Tourism Partnership - in 1992 is generally considered to be an early milestone in the 'greening' of the tourism industry. Additionally, it has produced guidelines on environmental best practices, most notably their manual 'Environmental Management for Hotels' and 'Green Hotelier' magazine (International Tourism Partnership, 2011; Kirk, 1995). Since the early years, the concept of EM in the accommodations sector has been increasingly discussed by academics and practitioners alike, though research has not necessarily kept pace with the implementation strategy (Bohdanowicz, 2005). While greening efforts have expanded, researchers have shown some skepticism regarding their sincerity (Brown, 1996; Honey, 1999; Saha and Darnton, 2005). However, given the contemporary changes in the global tourism industry and other industries as a whole with respect to greening efforts, it is apparent that more sincere application in EM initiatives will continue to evolve (Pizam, 2009).

Similar to the manufacturing industry, EM in the accommodations sector generally began with changes in basic technologies and policies. These technologies have been classified as 'ecotechniques', and include inter alia, equipment such as aerators for faucets and fluorescent bulbs (which reduce the consumption of water and electricity respectively), solid waste management, use of biodegradable chemicals, and a purchasing policy that supports these initiatives (Alvarez Gil et al., 2001; Ayala, 1995; Enz and Siguaw, 1999). Such ecotechniques allowed hotels to implement changes and realize efficiencies without the immediate intensive capital investments and/or involvement of many employees or guests (Alvarez Gil et al., 2001; Ayala, 1995). However, the establishment of a comprehensive environmental program or an environmental management system (EMS) may become more desirable as a hotel expands its initiatives or seeks a more systematic way of environmental management (Nikolaou et al., 2012). Ecotechniques have been described as the most basic form of environmental management, while EMS developed along the lines of a quality management system, is perhaps the most complicated (Ayuso, 2007). The International Organization for Standardization's ISO 14001 describes EMS and provides guidance on how the standard should be used (Tribe et al., 2000). Key criteria include (1) setting an environmental policy, (2) reviewing the organization's operations and identifying environmental aspects, (3) developing a structured program which includes setting and achieving objectives and targets, and (4) undertaking periodic audits and corrective action as necessary (Tribe et al., 2000).

Unlike the manufacturing sector in which improvement in pollution generation practices were necessary because of government regulations (Meyer, 2000; Walley and Whitehead, 1994), EM in the accommodations sector has generally been voluntary, following the 'clan' approach to regulation (Hjalager, 1996). The 'clan' approach is self-regulation which the industry may deem to be more appropriate in lieu of formal binding governmental regulations (Hjalager, 1996). The voluntary approach also extends to environmental certification whereby companies choose to be certified against a specific standard. A number of certification or eco-labeling programs have been developed in the past twenty years at local, regional and international levels (Font and Buckley, 2001). Such programs include Green Seal (U.S.), Nature Ecotourism Accreditation Program (Australia), Certification for Sustainable Tourism (Costa Rica), Eco-Management and Audit Scheme (EMAS) (UK), Quality Tourism for the Caribbean (regional), Nordic Ecolabeling (regional), EU Flower (European Union), Green Globe (international), ISO 14001 (international), and Global Sustainable Tourism Council (international). In the U.S., California, Florida, Maine, Michigan, New Hampshire, Vermont, Virginia, and Wisconsin have also established green lodging certification programs, while North Carolina and Pennsylvania have statewide initiatives to encourage green hotels (Hasek, 2007).

Since the evolution of basic initiatives to more advanced certified EMS, it is apparent that a range of EM have been implemented across the sector. Additionally, the willingness to adopt EM initiatives is largely related to various motivational factors which are likely facilitated by internal and external incentive programs. The question is what drives managers or owners to adopt environmental management practices in their operations. Researchers have elicited diverse motives for adopting environmental management, and can be categorized into three broad categories: cost and efficiency (e.g., potential cost savings), external pressures (e.g., government regulations) and internal forces (e.g., internal green champion) (Alvarez Gil et al., 2001; Ayuso, 2007; Bohdanowicz, 2005; Bramwell and Alletorp, 2001; Goodman, 2000; Lin and Hemmington, 1997; Tzschentke et al., 2008). Generally, such motives for implementation are usually facilitated by government incentives (e.g., tax credits) and associated employee capacity building initiatives (e.g., training) (Ayuso, 2007; Bramwell and Alletorp, 2001; Molina-Azorin et al., 2009).

Conversely, that lack of adoption is also determined by numerous barriers or constraints perceived or experienced by a property. Multiple barriers or constraints have been identified based on types of properties, ownership, and location which can be broadly categorized as: cost benefit (e.g., implementation is costly), organizational (e.g., lack of knowledge), and technical (e.g., lack of access to appropriate technology) (Ayuso, 2007; Bramwell and Alletorp, 2001; Chan, 2008; Hobson and Essex, 2001; Knowles et al., 1999; Post and Altman, 1994; Stabler and Goodall, 1997; Tzschentke et al., 2008; Vernon et al., 2003). Overall, motives, facilitators, and constraints are key drivers and barriers in the implementation of EM initiatives. The following section will provide additional details about these constructs and its influence on EM implementation.

\subsection{Motives}

The decision to implement any form of EM is a major decision for a hotel and is usually related to varying motives. A major motive or the number one motive in some cases is the prospect of reduced operational costs from decreased consumption of resources such as water and energy, and the generation of solid waste (Alvarez Gil et al., 2001; Ayuso, 2007; Bohdanowicz, 2005; Bramwell and Alletorp, 2001; Goodman, 2000). Pressure from external forces such as the government, wider tourism industry, trade associations, and the market (both direct and indirect) are listed reasons to implement EM schemes (Alvarez Gil et al., 2001; Ayuso, 2007; Bohdanowicz, 2005; Bramwell and Alletorp, 2001; Kasim, 2009; Vernon et al., 2003). Also, an EM strategy simply made good business sense (Ayuso, 2007; Bohdanowicz, 2005; Bramwell and Alletorp, 2001; Goodman, 2000; Molina-Azorin et al., 2009). Moreover, the driving force appears to be internal factors which includes recognition that the natural environment is important to the individual hotel; the manager/owner's concern about natural 
resources and acceptance of a moral/ethical responsibility to take action to conserve; expectation of gaining a competitive advantage; prospect of using environmental stewardship to diversify and expand market; and the expectation of an improved public image in recognition of initiatives (Ayuso, 2007; Bohdanowicz, 2005; Bramwell and Alletorp, 2001; Goodman, 2000; Lopez-Gamero et al., 2011; Priego et al., 2011; Tzschentke et al., 2008; Vernon et al., 2003).

\subsection{Facilitators}

The literature on EM has largely focused on motives and constraints with less attention given to drivers that facilitate the process. While acknowledged that some facilitators may be considered within the context of motives or constraints, however; it is defined in this research as drivers that assist a property to engage in basic EM implementation or upgrade to an advance level of EM. Capacity building initiatives, externally funded training projects, and government incentives have been highlighted as facilitators to implement EM (Ayuso, 2007; Bramwell and Alletorp, 2001). However, education has been suggested as important means to increase the adoption of EM in the accommodations sector (Molina-Azorin et al., 2009; Nikolaou et al., 2012; Samdin et al., 2012). Awareness is particularly important for small and medium sized businesses, since the lack of knowledge and understanding are often noted as barriers to adoption (Chan, 2011; Kasim, 2007; Samdin et al., 2012). Government incentives such as tax breaks and training at reduced costs, and other offers by local hotel and tourism associations may ease the adoption of environmental best practices (Kasim, 2007). Additionally, the development of guidelines, information, fiscal incentives, and support from public agencies have been suggested as means to facilitate implementation of EM in hotels (Hobson and Essex, 2001; Meade and Pringle, 2001; Molina-Azorin et al., 2009; Nikolaou et al., 2012; Samdin et al., 2012).

\subsection{Constraints}

The interest and intention of EM adoption in hotels is evident; however, the practice has simply not kept pace due to various constraints such as costs; interest, knowledge and technical support; complexity; human resources, and time (Ayuso, 2007; Bramwell and Alletorp, 2001; Chan, 2008; Hobson and Essex, 2001; Knowles et al., 1999; Post and Altman, 1994; Stabler and Goodall, 1997; Tzschentke et al., 2008; Vernon et al., 2003). Costs have been the paramount constraint to EM implementation. Constraints related to costs include, lack of implementation budget and high expense related to such action, higher capital investment, higher operating costs, and unprofitability (Ayuso, 2007; Bramwell and Alletorp, 2001; Chan, 2008; Hobson and Essex, 2001; Post and Altman, 1994; Stabler and Goodall, 1997; Tzschentke et al., 2008; Vernon et al., 2003; Zurburg et al., 1995). In the early years of EM, hoteliers suggested that they were already doing enough for the environment and did not need to take further action (Zurburg et al., 1995). Hence, this thought is still maintained by certain sectors, and the lack of interest in environmental concerns has been noted as a barrier to implement EM (Hobson and Essex, 2001; Stabler and Goodall, 1997). In some cases, hoteliers also have a narrow perspective on their property's environmental responsibility (Kasim, 2007). Additionally, some hoteliers remain unaware of environmental issues and their accommodation's impacts on the natural environment. Furthermore, even those with the interest have limited knowledge of sustainable practices and/or availability of resources to support initiatives (Hobson and Essex, 2001; Leslie, 2007).
Several studies have found the complexity of EM and the need to collaborate with external parties as barriers (Ayuso, 2007). Hoteliers indicated that the required organizational and administrative changes could be overwhelming, particularly where the business had not been very structured prior to the establishment of EMS (Ayuso, 2007). Kasim (2007) noted that some environmental measures may be difficult to incorporate into operations as they may be perceived to cause a lower quality of guest service. Finally, EM success depends on the management's philosophy and employee support, so negative attitudes (e.g., resistance to change) do present obstacles to adoption (Ayuso, 2007; Bramwell and Alletorp, 2001; Lopez-Gamero et al., 2011; Priego et al., 2011). Even in cases where staff may be receptive, management's reluctance or inability to allocate human resources has proven to be a deterrent (Hobson and Essex, 2001; Lopez-Gamero et al., 2011; Stabler and Goodall, 1997; Vernon et al., 2003).

\subsection{Purpose of study and research questions}

The purpose of this study was to determine hoteliers' 1) motives, facilitators, and constraints to EM implementation; and 2) factors (motives, facilitators, and constraints) that influence implementation of EM. Four research questions were formulated and empirically tested based on a two-part process. First, descriptive statistics were initially conducted (RQ1) to describe the basic features of the constructs with respect to EM. Following basic summaries, statistical analysis (RQ2, RQ3, and RQ4) were used to assess the influence of each construct with respect to the level of EM implementation.

- Research Question 1: What are the motives, facilitators, and constraints to EM implementation in the accommodations sector?

- Research Question 2: What motives influence the level of EM implementation in the accommodations sector?

- Research Question 3: What facilitators influence the level of EM implementation in the accommodations sector?

- Research Question 4: What constraints influence the level of EM implementation in the accommodations sector?

\section{Methods}

\subsection{Data collection E' sample}

This study was conducted among various types of accommodations in 19 countries of the English-speaking Caribbean. ${ }^{3}$ The study targeted general managers, owners, and environmental officer/manager of properties since these individuals are responsible for strategic decision making. Hotel selection was based on membership in the Caribbean Hotel Association ${ }^{4}$ (CHA) or the individual country's National Hotel Association (NHA). A database was compiled using CHA's membership list in combination with membership lists from the 19 NHA.

Data were collected through an Internet-based, ${ }^{5}$ useradministered questionnaire. This method was, chosen for several reasons: sample covered a wide geographic range; database

\footnotetext{
${ }^{3}$ Only the English speaking countries were chosen as the survey was conducted in the English language. Other, countries would require the survey to be conducted in other languages such as Spanish, French, Dutch, etc.

${ }^{4} \mathrm{CHA}$ (www.caribbeanhotelandtourism.com/) is an alliance of $35 \mathrm{NHA}$ throughout the English, Spanish, Dutch, and French sub-regions of the Caribbean.

5 The questionnaire was created and accessed through Zoomerang ${ }^{\mathrm{TM}}$, an online survey tool. A pilot study was, conducted to test for content and face validity, and user-friendliness of the online survey. No problems reported.
} 
Table 1

Number of Accommodation units by country and respondents.

\begin{tabular}{lcc}
\hline Country & $\begin{array}{l}\text { \# of } \\
\text { Accommodation Units }\end{array}$ & $\begin{array}{l}\text { Total \# of } \\
\text { respondents \% (N) }\end{array}$ \\
\hline Anguilla & 25 & $2.6(5)$ \\
Antigua and Barbuda & 39 & $5.1(10)$ \\
Bahamas & 59 & $7.2(14)$ \\
Barbados & 76 & $10.8(21)$ \\
Belize & 41 & $11.8(23)$ \\
Bermuda & 33 & $2.6(5)$ \\
British Virgin Islands & 32 & $1.0(2)$ \\
Cayman Islands & 44 & $2.1(4)$ \\
Dominica & 29 & $10.3(20)$ \\
Grenada & 29 & $5.1(10)$ \\
Guyana & 35 & $0.5(1)$ \\
Jamaica & 124 & $8.2(16)$ \\
Montserrat & 9 & $0.5(1)$ \\
St. Kitts \& Nevis & 19 & $3.6(7)$ \\
St. Lucia & 67 & $5.1(10)$ \\
St. Vincent \& the Grenadines & 47 & $6.7(13)$ \\
Trinidad \& Tobago & 64 & $9.2(18)$ \\
Turks \& Caicos Islands & 31 & $2.6(5)$ \\
United States Virgin Islands & 41 & $5.1(10)$ \\
\hline
\end{tabular}

a From Caribbean Hotel Association and National Hotel Associations' Databases.

indicated that the majority of hotels had email addresses and a website, and online surveys have been found to have a quicker return rate and in some instances, the same or significantly higher response rate than mail surveys, particularly for groups that frequently use email or the Internet (Kaplowitz et al., 2004). In order to ensure invitations would reach their intended targets, email addresses were verified through telephone calls to the hotels.

Additionally, a pre-notice was first emailed to alert the hotelier to expect an invitation to participate followed by an email with a URL link. A total of four email reminders were sent to boost response rate.

A total of 920 hotels were compiled in the database, however, despite numerous phone calls to each listed property to confirm an appropriate email address, a number of emails did not reach the intended recipient. Total respondents represented 197 hotels across 19 countries with at least one from each country (see Table 1$)$. The total response rate (27\%) was relatively low; however, multiple attempts to increase responses were conducted. Given the response rate, an attempt was made to determine whether non-response bias existed. However, extensive analysis on non-respondents proved difficult since the identities of respondents were anonymous. Through a comparison with the CHA database, respondents and non-respondents were found to be similar with regards to size. For both groups, two thirds were small hotels (75 rooms or less).

Based on the profile of respondents, small hotels (1-75 rooms) comprised of $73 \%$ of the sample, while medium hotels (76-500 rooms) and large hotels (501+) were $25 \%$ and $3 \%$, respectively. A quarter $(25 \%)$ of the sampled hotels were established in $2000 ; 28 \%$ in the 1990 s, and $18 \%$ noted 1980 s. Hotels were categorized as budget (19\%), mid-range (47\%) or luxury properties (34\%). Sixty one percent were locally owned and operated; $10 \%$ were foreign owned and operated, and $14 \%$ were foreign owned and locally operated. Hotels that were part of an international and locally operated chain or group comprised, of $9 \%$ and $5 \%$ respectively.

Most respondents were general managers (41\%), owners (10\%), owner/general managers (24\%), and others - environmental officers/managers (25\%). Hotel guests originated in the U.S. (61\%), while $19 \%$ were from the U.K. and 11\% from the Caribbean. Average annual occupancy ranged as $32 \%$ had $50 \%$ or less; $45 \%$ reported $51-$ $75 \%$, and almost $23 \%$ experienced occupancies over $75 \%$. Also, the

\footnotetext{
${ }^{6}$ Membership was not exclusive to one category.
}

majority (83\%) were members ${ }^{6}$ of their respective NHA; $77 \%$ were members of $\mathrm{CHA} ; 44 \%$ were representative of CAST, while $42 \%$ noted Other Green Organizations.

\subsection{Instrumentation}

The questionnaire was designed to solicit evaluation of EM by general managers, owners, and other environmental officers/ managers at their respective hotels. The questionnaire consisted of five sections which measured variables that pertained to motives, facilitators, constraints, and EM. Property characteristics such as location, type, ownership, and size were also determined. The constructs in the questionnaire were adapted from the literature with additional researcher determined items. Motives to implement EM were operationalized with eight items reflective of three themes: (1) cost reduction and efficiency, (2) internal forces, and (3) external pressure (Ayuso, 2007; Bohdanowicz, 2005; Bramwell and Alletorp, 2001; Stabler and Goodall, 1997; Vernon et al., 2003). Facilitators to implementation of EM were measured via six items related to two themes: (1) capacity building, and (2) incentives (Ayuso, 2007; Bramwell and Alletorp, 2001). Constraints to implementation of EM were measured with 12 items based on three themes: (1) cost benefit, (2) organizational, and (3) technical (Ayuso, 2007; Bramwell and Alletorp, 2001; Hobson and Essex, 2001; Post and Altman, 1994; Stabler and Goodall, 1997; Vernon et al., 2003; Zurburg et al., 1995). All items within the three major constructs of motives, facilitators, and constraints were measured on a five point Likert type scale with a range of $1-5$, where 1 = Strongly disagree, 2 = Disagree, 3 = Neither agree nor disagree, $4=$ Agree, and $5=$ Strongly agree. Also, an open-ended section was offered to capture any additional comments.

Since the early 1990s, research indicates that a range of EM from basic initiatives to advanced, environmental management system certification has been implemented. Accordingly, in this study, two major categories were noted as: Basic EM and Advanced EM. Basic EM relates to the adoption of elementary environmental best practices (e.g., energy saving lights, recycling), while Advanced EM relates to the commitment by a property toward environmental management initiatives. These can range from an internal environmental policy and planned actions across all units of the property to adoption of an externally certified comprehensive EMS. In this study, the level of EM was measured as a single item which asked respondents to indicate their environmental management initiatives at their respective property from Basic EM (Environmental Best Practices) to Advanced EM (Environmental Program, Environmental Management System, and Certified Environmental Management System):

\section{Basic EM}

(1). Environmental Best Practices: Some environmental best practices in place (e.g., aerators, energy saving lights, low flush toilets, low flow shower heads, towel/linen reuse program, solid waste separation for reuse or recycling).

\section{Advanced EM}

(2). Environmental Program: An environmental policy and planned actions throughout the property (involving all or most departments) to reduce consumption of resources and generation of waste.

(3). Environmental Management System: An environmental policy and a comprehensive program to reduce consumption of resources and generation of waste. Program includes objectives, targets, and action plan, performance monitoring and 
Table 2

Motives to implement environmental management (percentage).

\begin{tabular}{|c|c|c|c|c|c|c|}
\hline Questionnaire Statement $^{\mathrm{a}}$ & SD & $\mathrm{D}$ & $\mathrm{N}$ & A & SA & Mean $^{\mathrm{b}}$ \\
\hline \multicolumn{7}{|l|}{ Cost reduction E' efficiency } \\
\hline Potential cost savings & 3.4 & 1.7 & 12.7 & 35.6 & 46.6 & 4.20 \\
\hline Need to keep up with competitors & 15.9 & 17.8 & 26.2 & 30.8 & 9.3 & 3.00 \\
\hline $\begin{array}{l}\text { Advantage over competitors } \\
\text { Internal forces }\end{array}$ & 7.1 & 12.5 & 17.9 & 37.5 & 25.0 & 3.61 \\
\hline $\begin{array}{l}\text { Importance of conserving } \\
\text { natural resources }\end{array}$ & 2.4 & 0.0 & 2.4 & 24.0 & 71.2 & 4.62 \\
\hline Internal Green Champion & 10.4 & 12.5 & 28.1 & 27.1 & 21.9 & 3.38 \\
\hline $\begin{array}{l}\text { Pressure from shareholders } \\
\text { External pressure }\end{array}$ & 20.2 & 21.3 & 28.7 & 21.3 & 8.5 & 2.77 \\
\hline $\begin{array}{l}\text { Pressure from guests, tour } \\
\text { operators, travel agents, etc. }\end{array}$ & 23.8 & 20.8 & 30.7 & 20.8 & 4.0 & 2.60 \\
\hline Government regulations & 22.7 & 29.9 & 28.9 & 11.3 & 7.2 & 2.51 \\
\hline
\end{tabular}

${ }^{a}$ To what extent would you agree that the following items motivated your property to implement environmental management? SD = Strongly disagree (1); $\mathrm{D}$ = Disagree (2); $\mathrm{N}=$ Neither agree nor disagree (3); $\mathrm{A}=$ Agree (4); SA = Strongly agree (5).

b Mean value of each item based on a five point Likert type scale.

feedback, participation at all staff levels, documentation of all environmental and social initiatives.

(4). Certified Environmental Management System: Certification against a recognized standard (e.g., Local Authority or Environmental Agency, Green Globe, ISO 14001).

\section{Results}

\subsection{Environmental management}

Among the respondents, $67 \%$ reported to have implemented some level of EM. In fact, $32 \%$ noted their implementation of EM efforts before 2000 , and $68 \%$ reported adoption after 2000 or later. Hotels that implemented any level of EM were small with 75 rooms or less (69\%), mid-range (45\%) or luxury (39\%) properties that were locally owned and operated (52\%). Of these properties, $44 \%$ had implemented basic environmental best practices; $25 \%$ had an environmental program; $14 \%$ had an environmental management system; and $17 \%$ were certified against a recognized standard (e.g., Local Authority or Environmental Agency, Green Globe, ISO 14001). Given the variation in adoption and for testing of research questions based on logistic regression, the level of EM were recoded into two levels Basic EM (44\%) and Advanced EM (56\%). The Advance EM category was computed with - properties that had an environmental program; EMS; and a certified EMS. These three segments represented an advanced level of commitment toward EM initiatives.

\subsection{Research questions}

Research Question 1: What are the motives, facilitators, and constraints to EM implementation in the accommodations sector?

\subsubsection{Motives}

The importance of conserving natural resources and potential cost savings were overwhelmingly cited as the top two motives to implement EM. Ninety-five percent of respondents were in agreement and $2 \%$ in disagreement ${ }^{7}$ about the importance to conserve natural resources; while $82 \%$ agreed that implementation as a potential cost savings as a motive, while $5 \%$ disagreed (see Table 2 ). Other motives identified were advantage over competitors (63\%

\footnotetext{
${ }^{7}$ Agreed/agreement represents agreed combined with strongly agreed responses, while disagreed/disagreement, represents disagreed combined with strongly disagreed responses.
}

Table 3

Facilitators to implement environmental management (percentage).

\begin{tabular}{|c|c|c|c|c|c|c|}
\hline Questionnaire Statement $^{\mathrm{a}}$ & SD & $\mathrm{D}$ & $\mathrm{N}$ & A & SA & Mean $^{\mathrm{b}}$ \\
\hline \multicolumn{7}{|l|}{ Capacity building } \\
\hline In-house training & 2.6 & 3.4 & 11.1 & 54.7 & 28.2 & 4.03 \\
\hline Participation in external training & 7.6 & 11.4 & 19.0 & 46.7 & 15.2 & 3.50 \\
\hline $\begin{array}{l}\text { Technical assistance from external } \\
\text { agencies }\end{array}$ & 10.5 & 11.4 & 21.9 & 45.7 & 10.5 & 3.34 \\
\hline \multicolumn{7}{|l|}{ Incentives } \\
\hline Funding (e.g., external grants) & 30.2 & 20.8 & 31.3 & 10.4 & 7.3 & 2.44 \\
\hline $\begin{array}{l}\text { Government incentives (e.g., tax } \\
\text { credits, duty free concessions) }\end{array}$ & 43.5 & 19.6 & 22.8 & 8.7 & 5.4 & 2.13 \\
\hline $\begin{array}{l}\text { Project assistance (e.g., participation in } \\
\text { national or regional greening project) }\end{array}$ & 19.6 & 15.5 & 25.8 & 25.8 & 13.4 & 2.98 \\
\hline
\end{tabular}

agreement); internal green champion (49\% agreement); and the need to keep up with competitors ( $40 \%$ agreement). There were several items that hoteliers did not consider to be strong motives to implement EM. Government regulations were considered to be the least important motive. However, 19\% agreed that government regulations motivated their hotels to implement EM. Pressure from guests, tour operators, travel agents etc. and from shareholders were also considered to be lesser factors behind hotels' environmental initiatives.

Based on composite mean values, hotels were motivated to implement EM primarily because of the importance of natural resource conservation, potential cost savings, advantage over competitors, and because of an internal green champion. Analysis of openended comments revealed that hoteliers indicated motives such as, to take care of the environment for the sake of children and future generations, educate staff and guests, live up to the company's social responsibility, improve the lives and livelihood of local communities, and simply because it was 'common sense' or the right thing to do.

\subsubsection{Facilitators}

In-house training was the most popular facilitator of EM as 83\% were in agreement and $6 \%$ in disagreement. Participation in external training was also a strong contributor to the implementation of hotels' efforts, with $62 \%$ in agreement and $19 \%$ in disagreement (see Table 3). The third most popular facilitator was technical assistance provided by external agencies as 56\% agreed and $22 \%$ disagreed. There were two items that were not very helpful to implement EM: government incentives (e.g., tax credits, duty free concessions) and funding (e.g., external grants). Sixty three percent disagreed that government incentives was a facilitator, and $51 \%$ disagreed that funding was a facilitator. Thirty-nine percent of hoteliers agreed that participation in projects helped them to implement EM, while 35\% disagreed.

Based on composite mean values, there were several factors regarded as facilitators of EM. The top three facilitators were inhouse training, external training, and technical assistance from external agencies. Project assistance, funding, and government incentives were weak facilitators. In addition, open ended comments indicated participation in corporate programs, suggestions from guests, and adoption of a pioneer approach. Some respondents also noted the projects in which their hotel had participated, or the agencies $^{8}$ from which they received assistance.

\footnotetext{
${ }^{8}$ Assistance was provided through agencies such as CAST, Rainforest Alliance, Program for Belize, the Cayman, Islands National Trust, and the World Heritage Alliance for Sustainable Tourism.
} 
Table 4

Constraints to implement environmental management (percentage).

\begin{tabular}{|c|c|c|c|c|c|c|}
\hline Questionnaire Statement $^{\mathrm{a}}$ & SD & $\mathrm{D}$ & $\mathrm{N}$ & A & SA & Mean $^{\mathrm{b}}$ \\
\hline \multicolumn{7}{|l|}{ Cost benefit } \\
\hline Implementation is costly & 3.6 & 10.9 & 19.0 & 43.1 & 23.4 & 3.72 \\
\hline Lack of capital & 4.4 & 16.3 & 23.0 & 34.8 & 21.5 & 3.53 \\
\hline Lack of time & 7.5 & 32.8 & 17.9 & 32.8 & 9.0 & 3.03 \\
\hline & \multicolumn{3}{|c|}{ Organizational } & 13.1 & 2.2 & 2.47 \\
\hline $\begin{array}{l}\text { Making necessary organizational } \\
\text { changes is too difficult }\end{array}$ & 3.8 & 37.1 & 35.6 & 18.2 & 5.3 & 2.84 \\
\hline Employee resistance & 16.7 & 29.5 & 31.8 & 18.2 & 3.8 & 2.63 \\
\hline Lack of know-how & 11.5 & 30.9 & 28.1 & 25.2 & 4.2 & 2.80 \\
\hline $\begin{array}{l}\text { Environmental Management is not } \\
\text { necessary }\end{array}$ & 53.4 & 36.1 & 6.8 & 3.0 & 0.8 & 1.62 \\
\hline \multicolumn{7}{|l|}{ Technical } \\
\hline $\begin{array}{l}\text { More advanced level of environmental } \\
\text { management too difficult or } \\
\text { complicated }\end{array}$ & 3.0 & 21.2 & 37.1 & 31.8 & 6.8 & 3.18 \\
\hline $\begin{array}{l}\text { Current level of environmental } \\
\text { management is most appropriate } \\
\text { for the property }\end{array}$ & 6.6 & 31.4 & 27.7 & 27.7 & 6.6 & 2.96 \\
\hline No access to technology & 8.2 & 41.0 & 23.9 & 20.1 & 6.7 & 2.76 \\
\hline $\begin{array}{l}\text { Property unaware of any stage beyond } \\
\text { current level of environmental } \\
\text { management }\end{array}$ & 23.7 & 39.3 & 21.5 & 12.6 & 3.0 & 2.32 \\
\hline $\begin{array}{l}{ }^{a} \text { To what extent would you agree th } \\
\text { property in implementing environmental } \\
\mathrm{D}=\text { Disagree (2); } \mathrm{N}=\text { Neither agree nor } \\
\text { agree (5). }\end{array}$ & sagre & (1) & & & & Strongly \\
\hline
\end{tabular}

\subsubsection{Constraints}

Constraints were reported by those properties that had implemented EM in their respective hotels as well as those that had yet to do so. Thirty-nine percent agreed that more advanced level of EM was too difficult or complicated, while $24 \%$ disagreed (see Table 4 ). Thirty-four percent agreed that current level of EM was the most appropriate for their respective property and hence prevented them from advancing to another level. Ninety percent of respondents disagreed that EM was not necessary. Similarly, 63\% disagreed that lack of awareness was a constraint, while 59\% disagreed that potential benefits of implementation was not apparent. There were several other constraints that respondents disagreed more than agreed, namely - lack of access to technology, employee resistance, lack of know-how, and the difficulty in making organizational change.

Among the composite mean values, the top constraints identified were: implementation too costly, lack of capital, difficulty or complexity of a more advanced level of environmental management, and lack of time. Furthermore, based on open ended comments, respondents noted additional factors that prevented them to implement EM as: lack of or limited recycling facilities, issues with land tenure, too much paperwork, disinterest of locals in environmental management, tourism not taken seriously, and the perception that EM was not a government priority.

Research Question 2: What motives influence the level of EM implementation in the accommodations sector?

Logistic regression was used to determine the motives that influenced the level of EM implementation. All predictor variables were entered into the model which was estimated by the backward likelihood ratio $\operatorname{method}^{9}$ (see Table 5). The regression model at each step of the estimation was significant. However, the model at step 3 $\left(\chi_{(6)}^{2}=18.37 ; p<0.01\right)$ had the highest hit ratio $(70 \%)$ and

\footnotetext{
${ }^{9}$ This method of estimation was used for all subsequent logistic regressions.
}

Table 5

Level of environmental management on motives.

\begin{tabular}{|c|c|c|c|c|}
\hline & & B & SE & $\operatorname{Exp}(\beta)$ \\
\hline $\begin{array}{l}\text { Pressure from guests, tour operators, } \\
\text { travel agents, etc. }\end{array}$ & & -0.10 & 0.31 & 0.75 \\
\hline Pressure from shareholders & & -0.51 & 0.27 & 0.06 \\
\hline Internal Green Champion & & $0.90^{* *}$ & 0.27 & 0.00 \\
\hline Need to keep up with competitors & & 0.17 & 0.30 & 0.57 \\
\hline Government regulations & & 0.23 & 0.28 & 0.42 \\
\hline Potential cost savings & & -0.29 & 0.29 & 0.31 \\
\hline Model change $\chi^{2}$ & $18.37^{* *}$ & & & \\
\hline -2Log likelihood & 91.03 & & & \\
\hline Cox and Snell $R^{2}$ & 0.21 & & & \\
\hline Nagelkerke $R^{2}$ & 0.28 & & & \\
\hline Hosmer and Lemeshow $\chi^{2}$ & 6.22 & & & \\
\hline Hit ratio & 69.90 & & & \\
\hline
\end{tabular}

**Significant at 0.01 level (2-tailed).

contained 6 items (pressure from guests, tour operators, travel agents, etc., pressure from shareholders; internal green champion; need to keep up with competitors; government regulations; potential cost savings), of which one was statistically significant. This model accounted for $21-28 \%$ of the variation between basic EM and advanced EM $\left(R^{2}=0.21\right.$ (Cox and Snell), 0.28 (Nagelkerke). The non-significant Hosmer and Lemeshow test statistic indicated that the model fit the data well.

Controlling for other variables, the internal green champion item was significantly and positively, related to level of EM $(\beta=0.90, p<0.01, \operatorname{Exp}(\beta)=2.45)$. Therefore, a 1 unit increase in the motive (internal green champion) resulted in an increase by 0.90 in the predicted probability that a hotel would be in the advanced EM group. A 1 unit increase in internal green champion also increased the odds by $145 \%$ that a hotel would be in the advanced EM group. The odds are that hotels motivated by internal green champion would implement advanced EM.

Research Question 3: What facilitators influence the level of EM implementation in the accommodations sector?

Similarly, a logistic regression was performed to determine the facilitators that influenced the level of EM implementation (see Table 6). The regression model was not statistically significant at any step of the estimation, although the hit ratio increased from $55 \%$ to $62 \%$ at step 1 . The model change was not significant $\left(\chi^{2}(6)=5.88 ; p>0.05\right)$ and data fit was weak $\left[R^{2}=0.07\right.$ (Cox and Snell), 0.09 (Nagelkerke)]. There were no statistically significant relationships between facilitators and level of EM.

Research Question 4: What constraints influence the level of EM implementation in the accommodations sector?

Similarly, a logistic regression was performed on constraints and level of EM. The regression model at each step of the estimation was significant (see Table 7). The model at step $1\left(\chi_{(12)}^{2}=33.26\right.$; $p<0.001$ ) was retained as the number of significant items did not increase beyond this step. This model had a hit ratio of $74 \%$ (compared with 53\% at base) and explained between 37\% and 49\% of the variation between basic EM and advanced EM $\left[R^{2}=0.37\right.$ (Cox and Snell), 0.49 (Nagelkerke)]. With other variables held constant, six of the twelve constraint items were significantly related to level of EM: lack of capital $(\beta=-1.37, p=0.03, \operatorname{Exp}(\beta)=0.26)$; potential benefits not apparent $(\beta=0.78, p=0.04, \operatorname{Exp}(\beta)=2.19)$; no access to technology $(\beta=1.70, p<0.01, \operatorname{Exp}(\beta)=5.50)$; lack of know-how $(\beta=-1.24, p=0.02, \operatorname{Exp}(\beta)=0.29)$; lack of time $(\beta=-1.11$, $p=0.02, \operatorname{Exp}(\beta)=0.33)$; and $\mathrm{EM}$ is not necessary $(\beta=-2.08$, $p<0.01, \operatorname{Exp}(\beta)=0.13)$. 
Table 6

Level of environmental management on facilitators.

\begin{tabular}{|c|c|c|c|c|}
\hline & & B & SE & $\operatorname{Exp}(\beta)$ \\
\hline In-house training & & 0.14 & 0.29 & 1.15 \\
\hline Participation in external training & & 0.19 & 0.26 & 1.21 \\
\hline $\begin{array}{l}\text { Technical assistance from external } \\
\text { agencies }\end{array}$ & & 0.06 & 0.28 & 1.07 \\
\hline Funding (e.g., external grants) & & 0.24 & 0.33 & 1.27 \\
\hline $\begin{array}{l}\text { Government incentives (e.g., tax credits, } \\
\text { duty free concessions) }\end{array}$ & & -0.36 & 0.28 & 0.70 \\
\hline $\begin{array}{l}\text { Project assistance (e.g., participation in } \\
\text { national or regional greening project) }\end{array}$ & & 0.16 & 0.28 & 1.18 \\
\hline Model change $\chi^{2}$ & 5.88 & & & \\
\hline -2Log likelihood & 109.80 & & & \\
\hline Cox and Snell $R^{2}$ & 0.07 & & & \\
\hline Nagelkerke $R^{2}$ & 0.09 & & & \\
\hline Hosmer and Lemeshow $\chi^{2}$ & 6.34 & & & \\
\hline Hit ratio & 62.00 & & & \\
\hline
\end{tabular}

Lack of capital item was negatively related to level of EM. For a 1 unit increase in the lack of, capital, the predicted probability that a hotel would be in the advanced EM group decreased by 1.37, while the odds of this occurrence decreased by $74 \%$. The item, potential benefits not apparent was positively related to level of EM. For a 1 unit increase in potential benefits not apparent, the predicted probability that a hotel would be in advanced EM group increased by 0.78 , while the odds of this occurrence increased by $118 \%$. No access to technology item was positively related to level of EM. For a 1 unit increase in no access to technology, the predicted probability that a hotel would be in the advanced EM group increased by 1.70 , while the odds of this occurrence increased by $450 \%$. Lack of knowhow item was negatively related to level of EM. For a 1 unit increase in lack of know-how, the predicted probability that a hotel would be in the advanced EM group decreased by 1.24, while the odds of this occurrence decreased by $71 \%$. The item, lack of time was negatively related to level of EM. For a 1 unit increase in lack of time, the predicted probability that a hotel would be in the advanced EM group decreased by 1.11, while the odds of this occurrence decreased by $67 \%$. The item, EM is not necessary was also negatively related to level of EM. For a 1 unit increase in the item, EM is not necessary, the predicted probability that a hotel would be in the advanced EM group decreased by 2.08 , while the odds of this occurrence decreased by $88 \%$.

\section{Discussion}

Since the late 1990s, EM as an innovation has been increasing in the Caribbean's accommodations sector. This exploratory study was conceptualized to assess the extent to which greening had diffused; understand why hotels were inclined to implement this innovation; the factors that facilitated its implementation, and the associated challenges that prevents adoption. The following subsections offer an interpretation of the results, managerial and policy implications, limitations, and recommendations for future research.

\subsection{Motives for environmental management}

Based on descriptive results, the importance of conserving natural resources was the top motive for implementing EM. This is an important finding in light of the criticisms that have been leveled at the tourism industry, with regard to both its role in degrading natural resources, and the practice of 'greenwashing' (Butler, 1998; Honey, 1999). Natural resource conservation is especially important for the Caribbean's tourism industry due to its heavy dependence on terrestrial and marine resources for both traditional and alternative styles of tourism. With the survival of their businesses so heavily reliant on natural resources, hoteliers
Table 7

Level of environmental management on constraints.

\begin{tabular}{|c|c|c|c|c|}
\hline & & B & SE & $\operatorname{Exp}(\beta)$ \\
\hline $\begin{array}{l}\text { More advanced level of environmental } \\
\text { management too difficult or complicated }\end{array}$ & & 0.90 & 0.46 & 2.47 \\
\hline $\begin{array}{l}\text { Making necessary organizational } \\
\text { changes is too difficult }\end{array}$ & & 0.43 & 0.38 & 1.53 \\
\hline Implementation is costly & & 0.28 & 0.57 & 1.33 \\
\hline Lack of capital & & $-1.37^{*}$ & 0.62 & 0.25 \\
\hline Potential benefits not apparent & & $0.78^{*}$ & 0.39 & 2.19 \\
\hline No access to technology & & $1.70^{* *}$ & 0.59 & 5.50 \\
\hline Lack of know-how & & $-1.24^{*}$ & 0.53 & 0.29 \\
\hline Employee resistance & & 0.01 & 0.32 & 1.01 \\
\hline Lack of time & & $-1.11^{*}$ & 0.46 & 0.33 \\
\hline $\begin{array}{l}\text { Current level of environmental } \\
\text { management is most appropriate } \\
\text { for the property }\end{array}$ & & 0.05 & 0.32 & 1.05 \\
\hline Environmental management is not necessary & & $-2.08^{* *}$ & 0.76 & 0.12 \\
\hline $\begin{array}{l}\text { Property unaware of any stage } \\
\text { beyond current level of environmental } \\
\text { management }\end{array}$ & & -0.33 & 0.33 & 0.72 \\
\hline Model change $\chi^{2}$ & $33.26^{* *}$ & & & \\
\hline -2Log likelihood & 67.60 & & & \\
\hline Cox and Snell $R^{2}$ & 0.37 & & & \\
\hline Nagelkerke $R^{2}$ & 0.49 & & & \\
\hline Hosmer and Lemeshow $\chi^{2}$ & 4.73 & & & \\
\hline Hit ratio & 74.00 & & & \\
\hline
\end{tabular}

*Significant at 0.05 level.

**Significant at 0.01 level.

were perhaps more inclined to rank the conservation of resources highly. Another factor is that much resource degradation (e.g., marine pollution, coral bleaching and death) had become apparent in the Caribbean by the 1990s and beyond (McElroy and de Albuquerque, 1998). This evidence may have had some influence on Caribbean hoteliers. Hoteliers may also have been concerned about natural resources because they themselves reside in these communities or have personal interests in resource conservation. Their recognition of the importance of resource conservation is critical considering that tourists or activities to provide services to tourists generally consume significantly more water and energy than residents (Gopalakrishnan and Cox, 2003; TabatchnaiaTamirisa et al., 1997). Further, the accommodations sector actively competes with residents and other sectors for these limited resources.

Other motives included, protecting resources for children and future generations and being individually responsible for environmental preservation. Evidently, personal belief systems may influence decision making process to implement EM; a factor that was also highlighted by Dewhurst and Thomas (2003) and Tzschentke et al. (2008). Lopez-Gamero et al. (2011) further proposed that the commitment of hotel managers to EM is critical. This type of influence was exemplified by a Jamaican respondent who was motivated to implement EM because of "core values of personal responsibility, quality of life, concerns about providing next generation fair opportunities, global equality, love and appreciation for our mother earth." Understanding the influence of belief systems and norms is important since in small hotels and owner-operated hotels in particular, daily operations and policy decisions can easily be affected. Given that small hotels and owner-run properties constitute the majority of the Caribbean accommodations sector: this is crucial to the diffusion of EM.

Reduced cost has been heavily promoted as a significant benefit of implementing EM (International Hotels Environment Initiative, 1993; Meade and del Monaco, 1999; Meade and Pringle, 2001). Therefore, it is not surprising that potential cost savings emerged as a strong motive to implement EM since hotels are generally profitseeking enterprises, and greening has been perceived as a solid business strategy. Yet, it is noteworthy that support for this motive 
was not as strong as in other studies (Ayuso, 2007; Bohdanowicz, 2005; Bramwell and Alletorp, 2001; Tzschentke et al., 2008).

The prospect of gaining a competitive advantage over other hotels was the third most popular motive for implementing EM. Using EM to position one's hotel to be more attractive to the market and consequently increase room nights, is another benefit that has been used to encourage hotels (Meade and del Monaco, 1999). This study found that $75 \%$ of hotels did include EM in their marketing, and 55\% observed increases in room occupancy, which suggests that some competitive edge was gained via EM implementation.

Pressure from shareholders and pressure from guests, tour operators, travel agents, etc., were not popular motives for hoteliers. By contrast Lopez-Gamero et al. (2011) considered that such pressure could influence managers' perception of the importance of EM and by extension enhance a company's competitive advantage. Similarly, Ayuso (2007) also found stakeholders such as guest and tour operators to influential in management's decisions to adopt voluntary EM policies. Government regulations was the least likely item to motivate hoteliers to implement EM. This finding concurs with Ayuso (2007), Le et al. (2006) and Lopez-Gamero et al. (2011), as they found the hotel industry's environmental legislation or policies were either insignificant or negatively related to the implementation of environmental measures.

Based on the statistical analysis, only internal green champion proved to be a significant predictor of EM. The relationship between green champion and level of EM was positive. Thus, having an internal green champion increased a hotel's likelihood to implement an advanced level of EM. This finding is consistent with Rogers (2003) generalization that "the presence of an innovation champion contributes to the success of an innovation in an organization" (p. 414). As an indication of the importance of this role, one of the goals of Jamaica's Environmental Audits for Sustainable Tourism (EAST) was to "develop environmental champions ... to encourage adoption of best environmental management practices by others" (Brown-Thompson and Cresser, 2004, p. 98).

\subsection{Facilitators of environmental management}

Based on descriptive results, in-house training was the most often selected facilitator of EM within their respective property. Formal or informal in-house training helps to share information about greening with all levels of staff, and properly prepares them to implement the innovation. Training creates a 'buy-in' and consequently generates employee support for the innovation which is critical for successful implementation. In addition, participation in external training and technical assistance provided by external agencies were also noted as key facilitators. Since EM is an innovation, it would be expected that a certain degree of training would be required for successful implementation. This would be relevant as hotels progress from basic to more advanced EM. Participation in external training and technical assistance from outside agencies would also assist hotels to improve the capabilities of its staff, particularly where in-house expertise is deficient. Similar results were also reported by Bramwell and Alletorp (2001) as they found that technical expertise and advice from consultants were most often cited by hoteliers as external facilitators to adopt environmental best practices.

Project assistance received relatively weak support as a facilitator of EM. However, since 1997, at least four major projects funded (fully or partially) by international agencies have been conducted in the Caribbean which involved more than 500 properties in the Anglophone Caribbean (Blanchard and Lorde, 2004; Brown-Thompson and Cresser, 2004; Meade and Pringle, 2001). Of these projects, the Caribbean Hotels Environmental
Management Initiative (CHEMI) was primarily focused to develop, build and enhance capacity with respect to environmental management, especially among small-scale accommodations in the eastern Caribbean countries (CHEMI, 2004). Moreover, government incentives (e.g., tax credits, duty free concessions) received the lowest rating. Nevertheless, some countries have adopted policies to provide myriad incentives. For instance, the Government of Barbados via the Tourism Development Act (2002) encourages greening by offering hotels' tax concessions of $150 \%$ for "acquiring Green Globe or similar certification" (Part IV, $\S 31$ (b)), and duty free concessions on plumbing fittings (which may be water saving devices), energy saving bulbs and fittings, and waste water disposal and sewerage systems, among other items (Mycoo, 2006).

Although, respondents identified a number of facilitators to EM, but individually none were statistically significant predictor of EM. This was surprising given the extent of capacity building with respect to education and training in the region. However, unlike the incentive program at Barbados, such incentives are not widespread in the Caribbean region, and it is not surprising that most hoteliers rated government incentives as weak facilitators. Nevertheless, this construct needs to be further developed as there may be additional themes and items that may add to the predictive validity which were not included in this study.

\subsection{Constraints to environmental management}

The emphasis placed on cost and lack of capital constraints corresponds with much of the research on EM, where cost is seen as the primary barrier to adoption (Bramwell and Alletorp, 2001; Chan, 2011; Hobson and Essex, 2001; McNamara and Gibson, 2008). Similar to findings by Hobson and Essex (2001) and McNamara and Gibson (2008), lack of time was a constraint for $42 \%$ of the respondents. Since most of the hotels were small, this finding is understandable. A quarter of the properties in this study had 10 or less employees; $43 \%$ had 25 or less. For smaller properties with fewer staff, implementation of advanced levels of EM may prove to be very difficult. This position was also supported by responses to an open-ended question in which the requirements of advanced EM were presented as barriers by hoteliers who indicated that their properties were small with limited personnel. Lack of time was linked with costs in that some respondents felt that personnel did not have the time to work on EM, and hiring additional personnel would be too costly.

Based on the statistical analysis, six constraints items were significant predictors of EM. Of which, the items, lack of capital, lack of time, lack of know-how, and EM is not necessary may have prevented them from upgrading from their current to a more advanced group, since level of EM decreased as agreement with these constraints increased. However, two items (potential benefits not apparent, and no access to technology) demonstrated a positive relationship, which is unusual because as agreement with these constraints increased, so did the likelihood that hotels would be in the advanced EM group. In the case of the item, potential benefits not apparent, it may be that respondents in agreement were hotels that had already implemented an advanced level of EM and did not perceive any potential benefits with more advancement. For instance, managers/owners of hotels with an environmental program may not be convinced of the additional benefits to implement an EMS, which may require more staff and capital (Ayuso, 2007). Similarly, hotels with an EMS may not see the potential benefit of certification. The item, no access to technology may have similar circumstances, whereby hotels have already moved beyond basic environmental best practices, but are unable to implement an advanced level of EM. 


\subsection{Management and policy implications}

The survival of the Caribbean accommodations sector depends to a large extent on the quality of the natural environment. Therefore, the accommodations sector has an important role in protecting natural resources. One way to enhance protection is for properties to implement EM. Reducing consumption of resources lessens demand in the wider community and decreases competition for scarce resources. Further, increased efficiencies translate into lowered costs and more money at the bottom line. EM in the Caribbean accommodations sector exhibited a range of characteristics. This should provide encouragement to those properties that may think their respective characteristics preclude them from EM implementation. Further, properties can choose how they want to initiate EM whether by implementing basic environmental best practices or through more advanced EM from the onset. While EM in its most advanced forms will involve most or all personnel within a property, the existence of a green champion is important. EM may have a better chance of success if there is at least one person within a property who really drives the process. As have been found in a range of diffusion studies, opinion leaders or change agents have strong influence (Rogers, 2003), and consequently is important to get more industry members to adopt a wider range of green practices.

Constraints to EM implementation were identified and may have prevented some hotels to implement EM; however such constraints can be negotiated. EM implementation, even at its most basic level is seldom an easy task. There is a need for the NHA and CAST to continue their efforts to raise awareness about the sector's impact on the environment and actions that can reduce those impacts. However, hoteliers should be proactive and lobby their associations to organize appropriate training for them. While the NHA may not be able to provide such services directly, they are better positioned to negotiate rates on behalf of their members through economies of scale. Additionally, CAST maintains a network of Technical Service Affiliates that hotels may find useful. The certified and well-known green champion properties in the region should also be used as a resource for hoteliers that seek to embark on EM initiatives. Given the results of this study, the following are recommended that can be applied to their respective destinations:

For Associations/Organizations:

NHA and CAST should continue to encourage and facilitate EM in hotels.

$\bigcirc$ Offer and/or facilitate training programs and technical expertise.

$O$ Influence governments to offer tax incentives for EM implementation.

For hotels:

$\bigcirc$ Initiate EM at the most comfortable level.

$O$ Consider a more advanced level of EM if basic EM has already been implemented.

Work collectively to access 'expert' training or work with hotel associations to do such.

$\bigcirc$ Think outside the box and tap resources which may be often overlooked (e.g., a science teacher at a local school to deliver a staff workshop).

Consider membership in National Associations and CAST if not yet a member.

For policy-makers:

Partner with other sectors to conserve resources.
Work with the industry to implement infrastructural changes (e.g., recycling) which will also benefit residents.

$\bigcirc$ Consider creating incentives (e.g., tax credits, duty free concessions) for properties to adopt environmental best practices.

\section{Limitations and recommendations}

This study was restricted to hotels within the Anglophone Caribbean though EM initiatives are also evident in the Spanish, French, and Dutch sub-regions. While this study may offer insight into EM, the findings should be considered within the context of the Caribbean. This study targeted general managers, owners and environmental officers of hotels because they are the decision makers with respect to EM initiatives. However implementation of EM, particularly at the advanced level, requires input from most, if not all personnel. Therefore, this study may have primarily captured one perspective. The study was also limited in that much of the focus was on properties that had adopted some level of environmental management. Therefore, there was a low level of variation between the responses to the questionnaire. Also, the characteristics of those properties that responded were very similar.

The research method for this study was an Internet based survey. This method is still developing and is relatively new to the Caribbean region. Hoteliers were invited to participate by email, and in spite of confirmation of email addresses for each hotel, many of the emails did not reach the intended recipient. Additionally, emails may have ended up as junk mail despite attempts to prevent this occurrence. Furthermore, the nature of email is that they can be read and easily forgotten if the subject is not a priority. Another limitation of the study was the time frame (Dec-Feb are peak tourism season) in which the data was collected which limited the response rate, as response may have been considered as a low priority. The response rate to the survey, though acceptable, was somewhat lower than anticipated.

This study was primarily quantitative. More in-depth qualitative studies are recommended, whether by individual country, hotel characteristic, or other basis. Qualitative studies may be able to investigate the nuances that this study may have missed. This study was conducted in the Anglophone Caribbean which represents less than half of the Caribbean accommodations sector with respect to the quantity of room inventory. In order to reach a more comprehensive understanding of EM in the region, it is recommended that future research be extended to include hotels in the Spanish, French, and Dutch Caribbean.

\section{References}

Alvarez Gil, M.J., Burgos, J., Cespedes Lorente, J.J., 2001. An analysis of environmental management, organizational context and performance of Spanish hotels. Omega 29 (6), 457-471.

Ayala, H., 1995. Ecoresort: a 'green' masterplan for the international resort industry. International Journal of Hospitality Management 14 (3-4), 351-374.

Ayuso, S., 2007. Comparing voluntary policy instruments for sustainable tourism: the experience of the Spanish Hotel Sector. Journal of Sustainable Tourism 15 (2), 144-159.

Bacon, P.R., 1987. Use of wetlands for tourism in the insular Caribbean. Annals of Tourism Research 14 (1), 104-117.

Best, M., 2002. The greening of Barbados' tourism industry: the private sector role. Paper Presentation at the Caribbean Waste Water Association's Conference \& Environmental Forum, St. Lucia. October 7-11.

Best, M., 2004. Barbados' Green Globe 21 hotels: a reflection on their journey. Paper Presentation at the Green Globe 21 Conference on Sustainable Tourism, New Zealand. March 3-5.

Bigoness, W.J., Perreault, W.D., 1981. A conceptual paradigm and approach for the study of innovators. Academy of Management Journal 24,68-82.

Blanchard, J., Lorde, D., 2004. Sustainable tourism in the Caribbean: the experience of small hotels implementing environmental management systems. Paper Presentation at the Green Globe 21 Conference on Sustainable Tourism, New Zealand. March 3-5. 
Bohdanowicz, P., 2005. European hoteliers' environmental attitudes: greening the business. Cornell Hotel and Restaurant Administration Quarterly 46 (2), 188-204.

Bramwell, B., Alletorp, L., 2001. Attitudes in the Danish tourism industry to the roles of business and government in sustainable tourism. The International Journal of Tourism Research 3 (2), 91-103.

Brown, M., 1996. Environmental policy in the hotel sector: "Green" strategy or stratagem? International Journal of Contemporary Hospitality Management 8 (3), $18-23$.

Brown-Thompson, R., Cresser, H., 2004. Environmental management and sustainability at a national level. Paper Presentation at the Green Globe 21 Conference on Sustainable Tourism, New Zealand. March 3-5.

Burke, R.I., 2007. Environment and Tourism: Examining the Relationship between Tourism and the Environment in Barbados and St. Lucia. Caribbean Policy Development Centre, Bridgetown, Barbados.

Burke, L., Maidens, J., 2004. Reefs at Risk in the Caribbean. World Resources Institute, Washington, D.C.

Butler, R., 1998. Sustainable tourism - looking backwards in order to progress? In: Hall, M., Lew, A. (Eds.), Sustainable Tourism: A Geographical Perspective. Longman, New York, pp. 25-34.

Carrier, J.G., Macleod, D.V.L., 2005. Bursting the bubble: the socio-cultural context of ecotourism. Journal of the Royal Anthropological Institute 11 (2), 315-334.

Chan, E.S.W., 2011. Implementing environmental management systems in smalland medium-sized hotels: Obstacles. Journal of Hospitality \& Tourism Research 35 (1), 3-23.

Chan, E.S.W., 2008. Barriers to EMS in the hotel industry. International Journal of Hospitality Management 27 (2), 187-196.

CHEMI, 2004. Caribbean Hotels Environmental Management Initiative. Available in. http://pdf.usaid.gov/pdf_docs/PDACF125.pdf.

de Albuquerque, K., McElroy, J.L., 1995. Tourism development in small islands: St Maarten/St Martin and Bermuda. In: Barker, D., McGregor, D.F.M. (Eds.), Environment and Development in the Caribbean: Geographical Perspectives. University of the West Indies Press, Jamaica, pp. 70-89.

Dewhurst, H., Thomas, R., 2003. Encouraging sustainable business practices in a non-regulatory environment: a case study of small tourism firms in a UK national park. Journal of Sustainable Tourism 11 (5), 383-403.

Dilworth, V. A., 2003. Visitor perceptions of alternative transportation systems and intelligent transportation systems in national parks. Unpublished Ph.D. dissertation. Texas A\&M University, College Station, Texas.

Enz, C.A., Siguaw, J.A., 1999. Best hotel environmental practices. Cornell Hotel and Restaurant Administration Quarterly 40 (5), 72-75.

Font, X., Buckley, R., 2001. In: Tourism Ecolabelling: Certification and Promotion of Sustainable Management. CAB International, Wallingford, UK.

Goodman, A., 2000. Implementing sustainability in service operations at Scandic Hotels. Interfaces 30 (3), 202-214.

Gopalakrishnan, C., Cox, L.J., 2003. Water consumption by the visitor industry: the case of Hawaii. International Journal of Water Resources Development 19 (1), 29-35.

Gossling, S., 2002. Global environmental consequences of tourism. Global Environmental Change 12 (4), 283-302.

Hasek, G., 2007. More than 300 U.S. Hotels Now Certified 'green.'. Available in. http://www.greenbiz.com/news/2007/07/31/more-300-us-hotels-nowcertified-green.

Hjalager, A.M., 1996. Tourism and the environment: the innovation connection. Journal of Sustainable Tourism 4 (4), 201-218.

Hobson, K., Essex, S., 2001. Sustainable tourism: a view from accommodation businesses. Service Industries Journal 21 (4), 133-146.

Honey, M., 1999. Ecotourism and Sustainable Development: Who Owns Paradise? Island Press, Washington, D.C.

International Hotels Environment Initiative, 1993. Environmental Management for Hotels. Butterworth-Heinemann, Oxford, UK.

International tourism Partnership, About Us, 2011. Available in. http://www. tourismpartnership.org/about-us.

Kaplowitz, M.D., Hadlock, T.D., Levine, R., 2004. A comparison of web and mail survey response rates. Public Opinion Quarterly 68 (1), 94-101.

Kasim, A., 2009. Managerial attitudes towards environmental management among small and medium hotels in Kuala Lumpur. Journal of Sustainable Tourism 17 (6), 709-725.

Kasim, A., 2007. Towards a wider adoption of environmental responsibility in the hotel sector. International Journal of Hospitality \& Tourism Administration 8 (2), 25-49.

Kassinis, G.I., Soteriou, A.C., 2003. Greening the service profit chain: the impact of environmental management practices. Production \& Operations Management 12 (3), 386-402.

Kingsbury, P., 2006. Corporate environmental sustainability: sandals resorts international in Jamaica. In: Pugh, J., Henshall, J.M. (Eds.), Environmental Planning in the Caribbean. Ashgate Publishing, Ltd, UK, pp. 111-127.

Kirk, D., 1995. Environmental management in hotels. International Journal of Contemporary Hospitality Management 7 (6), 3-8.

Knowles, T., Macmillan, S., Palmer, J., Grabowski, P., Hashimoto, A., 1999. The development of environmental initiatives in tourism: responses from the London hotel sector. International Journal of Tourism Research 1 (4), 255-265.

Le, Y., Hollenhorst, S., Harris, C., McLaughlin, W., Shook, S., 2006. Environmental management: a study of Vietnamese hotels. Annals of Tourism Research 33 (2), 545-567.
Leslie, D., 2007. The missing component in the 'greening' of tourism: the environmental performance of the self-catering accommodation sector. International Journal of Hospitality Management 26 (2), 310-322.

Lin, Y.H., Hemmington, N., 1997. The impact of environmental policy on the tourism industry in Taiwan. Progress in Tourism and Hospitality Research 3 (1), 35-45. Lopez-Gamero, M., Molina-Azorin, J., Claver-Cortes, E., 2011. The relationship between managers' environmental perceptions, environmental management and firm performance in Spanish hotels: a whole framework. International Journal of Tourism Research 13 (2), 141-163.

McElroy, J.L., de Albuquerque, K., 1998. Tourism penetration index in small Caribbean islands. Annals of Tourism Research 25 (1), 145-168.

McNamara, K.E., Gibson, C., 2008. Environmental sustainability in practice? A macro-scale profile of tourist accommodation facilities in Australia's coastal zone. Journal of Sustainable Tourism 16 (1), 85-100.

Meade, B., Pringle, P., 2001. Environmental management systems for Caribbean hotels and resorts: a case study of five properties in Jamaica. Journal of Quality Assurance in Hospitality \& Tourism 2 (3), 149-159.

Meade, B., del Monaco, A., 1999. Environmental management: the key to successful operation. Paper Presentation at the First Pan-American Conference Latin American Tourism in Next Millennium: Education, Investment and Sustainability, Panama. May 19-21.

Meyer, H., 2000. The greening of corporate America. Journal of Business Strategy 21 (1), 38-43.

Molina-Azorin, J., Claver-Cortes, E., Pereira-Moliner, J., Jose Tari, J., 2009. Environmental practices and firm performance: an empirical analysis in the Spanish hotel industry. Journal of Cleaner Production 17 (5), 516-524.

Mowen, A.J., Confer, J.J., 2003. The relationship between perceptions, distance, and socio-demographic characteristics upon public use of an urban park "in-fill". Journal of Park and Recreation Administration 21 (3), 58-74.

Murphy, J., Olaru, D., Schegg, R., Frey, S., 2003. The bandwagon effect: Swiss hotels' web-site and e-mail management. Cornell Hotel and Restaurant Administration Quarterly 44 (1), 71-87.

Mycoo, M., 2006. Sustainable tourism using regulations, market mechanisms and green certification: a case study of Barbados. Journal of Sustainable Tourism 14 (5), 489-511.

Nikolaou, I.E., Vitouladitis, H., Tsagarakis, K.P., 2012. The willingness of hoteliers to adopt proactive management practices to face energy issues. Renewable and Sustainable Energy Reviews 16, 2988-2993.

Pizam, A., 2009. Green hotels: a fad, ploy or fact of life? International Journal of Hospitality Management 28 (1), 1.

Poon, A., 1987. Information technology and innovation in international tourismImplications for the Caribbean tourist industry. Unpublished PhD dissertation. University of Sussex, London.

Post, J.E., Altman, B.W., 1994. Managing the environmental change process: barriers and opportunities. Journal of Organizational Change Management 7 (4), 64-81.

Priego, M., Najerab, J., Font, X., 2011. Environmental management decision-making in certified hotels. Journal of Sustainable Tourism 19 (3), 361-381.

Rogers, E., 2003. Diffusion of Innovations, fifth ed. Free Press, New York.

Ryan, B., Gross, N., 1943. The diffusion of hybrid seed corn in two Iowa communities. Rural Sociology 8, 15-24.

Saha, M., Darnton, G., 2005. Green companies or green con-panies: are companies really green, or are they pretending to be? Business and Society Review 110 (2), 117-157.

Sahadev, S., Islam, N., 2005. Why hotels adopt ICTs: a study on the ICT adoption propensity of hotels in Thailand. International Journal of Contemporary Hospitality Management 17 (4/5), 391-401.

Samdin, Z., Bakori, K.A., Hassan, H., 2012. Factors influencing environmental management practices among hotels in Malaysia. World Academy of Science, Engineering and Technology 65, 432-435.

Sinclair, D., Jayawardena, C., 2003. The development of sustainable tourism in the Guianas. International Journal of Contemporary Hospitality Management 15 (7), 402-407.

Smith, W.L., 2007. Understanding diffusion of technology in rural entrepreneurship operations: a three year longitudinal study. International Journal of Innovation and Learning 4 (2), 160-171.

Stabler, M.J., Goodall, B., 1997. Environmental awareness, action and performance in the Guernsey hospitality sector. Tourism Management 18 (1), 19-33.

Strang, D., Soule, S.A., 1998. Diffusion in organizations and social movements: from hybrid corn to poison pills. Annual Review of Sociology 24 (1), 265-290.

Tabatchnaia-Tamirisa, N., Loke, M.K., Leung, P., Tucker, K.A., 1997. Energy and tourism in Hawaii. Annals of Tourism Research 24 (2), 390-401.

Tribe, J., Font, X., Griffiths, N., Vickery, R., Yale, K., 2000. Environmental Management of Rural Tourism and Recreation. Cassell, London, UK.

Tzschentke, A.N., Kirk, D., Lynch, P.A., 2008. Going green: decisional factors in small hospitality operations. International Journal of Hospitality Management 27 (1), $126-133$.

Vernon, J., Essex, S., Pinder, P., Curry, K., 2003. The 'greening' of tourism microbusinesses: outcomes of focus group investigations in South East Cornwall. Business Strategy and the Environment 12 (1), 49-69.

Walley, N., Whitehead, B., 1994. It's not easy being green. Harvard Business Review $72(3), 46-51$.

Wilkinson, P., 1987. Tourism in small island nations: a fragile dependence. Leisure Studies 6 (2), 127-146.

Zurburg, R., Ruff, D., Ninemeier, J., 1995. Environmental action in the United States lodging industry. Hospitality \& Tourism Educator 7 (2), 45-49. 